\title{
The Role of Export Diversification on Economic Growth in South Africa
}

\section{Caroline Mudenda}

Department of Economics, University of Fort Hare,

P. Bag X1314, Alice, 5700, South Africa

Email:mudenda@gmail.com

Ireen Choga

Department of Economics, University of Fort Hare,

P. Bag X1314, Alice, 5700, South Africa

Email: ichoga@ufh.ac.za

\section{Cleopas Chigamba}

Department of Business Management, University of Fort Hare,

P. Bag X1314, Alice, 5700, South Africa

Email: cchigamba@ufh.ac.za

\section{Doi:10.5901/mjss.2014.v5n9p705}

\section{Abstract}

\begin{abstract}
The paper examined "the role of export diversification on economic growth in South Africa". The study used annual time series secondary data for the period covering 1980 to 2010 and employed a Vector Error Correction Model to determine the effects of export diversification and possible factors that affect it on economic growth. Possible factors that affect export diversification considered as independent variables in this study include gross capital formation, human capital, real effective exchange rate and trade openness. Results of the study reveal that export diversification and trade openness are positively related to economic growth while real effective exchange rate, capital formation and human capital have negative long run relationships with economic growth. The study recommends the continual implementation of trade liberalisation by the South African government. The South African government is also encouraged promote the production of a diversified export basket through subsidisation and promotion of innovation and production of new products.
\end{abstract}

Keywords: Export diversification, Economic growth, South Africa

\section{Introduction and Background of the Study}

The role played by the diversification of exports on economic growth of a country has raised much debate recently in the economic field. The on-going debate is central on whether export diversification actually play a role in the growth of the economy. Subjective evidence suggests that almost there are no current developed countries with extremely high levels of export concentration (Agosin, Alvarez and Bravo-Ortega, 2009). Brenton, Newfarmer and Walkenhorst (2007) argued that export diversification makes countries to be less susceptible to adverse terms of trade shocks by stabilising export revenues. As a result it becomes easier to channel positive terms of trade shocks into growth, knowledge spill-overs and increasing returns to scale, creating learning opportunities principal to new forms of comparative advantage.

In most developing economies, the import substitution strategy has failed to promote the industrialisation process, resulting to export diversification failing to occur as expected. Furthermore, literature shows that the productive systems suffered significantly from high trade barriers and distorted relative prices (Nouira, Plane and Sekkat, 2009). In light of this, building new comparative advantage in new and non-traditional exports, including labour intensive manufactures, still remains a crucial objective for small economies. Manufactured exports are believed to support sustained overall economic growth for several reasons, the major reason being that the demand for manufactured goods increases more with income increases than the demand for primary products. Hence, growth prospects for a country's exports are higher by specialising in manufacturing.

Policy makers may use export diversification as a source of economic growth, in cases where the size of the domestic market is small and the existing export basket is concentrated in products that have inelastic demand (Chandra, 
Boccardo \& Osorio, 2007). In light of these circumstances, Chandra, et al. (2007) is of the view that diversification into non-traditional exports opens up new opportunities and new markets for firms. More so, Samen (2010) posit that traditional exports are to a larger extent at risk from exogenous shocks leading to limited demand owing to their low income elasticity and declining terms of trade. In addition, Samen (2010) lamented that diversifying away from traditional exports is expected to raise growth rates and lower their variability.

In the 1930s, South Africa has heavily embarked on the import substitution policy as a strategy of international trade and growth. This was mainly done to protect the important gold mining sector and the infant steel and iron industry from international competition (Du plessis, Smit, and McCarthy, 2000:174). This was mainly conducted using tariff imposition because South Africa was by then a member of the General Agreement on Tariffs and Trade (GATT) after the crushing of the Bretton woods and the Gold exchange systems. The Bretton woods and the Gold exchange systems disallowed the use of other import restrictions other than tariffs (Du plessis, et al., 2000: 154).

Later in the 1950s to 1970s, import substitution was perceived to have no significant contribution to growth of the country. Due to that perception, additional measures were proposed to provide a further stimulus to export manufacturers (Du plessis, et al., 2000: 176). However, all these changes did not lead to South Africa experiencing export oriented growth. Instead, the increased economic isolation of the country and perceived threats from the international community to the survival of the economy of South Africa led to further import substitution investment. This time the import substitution was based on the strategic industry argument. Though this strategy was not justified on economic grounds but was on the perceived environment of economic warfare, the strategy was successful. It saw South Africa increasing production on products such as armaments, synthetic rubber, diesel engines and further extensions to the petrochemical industry, consequently leading to the growth of the economy (Du plessis, et al., 2000: 176 - 179).

\section{Importance of the Study}

Though there are some suggested effects of export diversification on economic growth and competitiveness, there is no clear cut answer as to the existence and type of relationship between these two variables. This study sought to answer the questions that arise on the specific relationship between export diversification and economic growth, and the role it plays in the competitiveness of South Africa in international market. The study helps to determine the role that has been played by export diversification on economic development in the South African context. This study helps policy makers, the government, traders and the whole business community to know the role played and extent of the effect of export diversification on the growth and competitiveness of the economy. It also helps policy makers on which strategy to implement when it comes to international trade.

\section{Objectives of the Research}

The main objective of the study was to determine the possible relationship between export diversification and economic growth. The specific objectives are:

- To determine the composite of export products in South Africa.

- To analyse the export diversification process that has taken place in South Africa.

- To test the causal relationship between exports and output growth in South Africa.

- To determine the strength and direction of the relationship between export diversification and economic growth in South Africa.

\section{Literature Review}

The following sections (Section 4.1 and Section 4.2) present the evidence of supporting literature with regard to the study.

\subsection{Theoretical literature}

This section explores theoretical literature, with considerations made to static theories of trade, dynamic theories of trade and growth theories. 


\subsubsection{Heckscher-Ohlin theory}

The Heckscher-Ohlin theory argues that a country can only gain from international trade if it specialises in the production and exportation of the product basing on its comparative advantage (Salvatore, 2007:132). After countries engage in international trade, both countries are able to consume and produce beyond the initial levels of their Production Possibility Frontiers (PPFs) and indifference curves mainly due to specialisation. It therefore follows that export diversification comes naturally to countries endowed by a lot of production resources in relation to other countries. The theory is not always applicable in the real world as sources of comparative advantage may also come from continuous research and innovation not only from different relative factor endowments as suggested by the $\mathrm{H}-\mathrm{O}$ theory.

\subsubsection{The Imitation Lag Hypothesis}

The Imitation Lag Hypothesis takes into consideration the fact that technology among different countries also differ greatly in reality. The theory postulates that it takes time for technology to circulate among countries such that achieving identical technology in different countries is a rare or impossible phenomenon (Appleyard, Field, and Cobb, 2010). Any nation can therefore diversify its exports by engaging in continual research, innovation and production of new products. The imitation Lag hypothesis is closer to reality because technology is rarely identical among countries. To add on to that, it takes some time for a newly introduced product to be produced and consumed by other countries other than its initial producer.

\subsubsection{The Product Life Cycle}

The product life cycle theory states that the product is developed in mainly three stages. These stages are the new product stage, maturing stage and standardised stage. During the new product stage, demand for the product is equal to total domestic demand and no international trade is done (Ederington and McCalman, 2009). Foreign demand for the product begins to feature at the maturing stage and the producer may even consider starting production in foreign countries. At the standardised stage, most production of the product is moved to the developing countries and international trade continue to grow (Appleyard, et, al., 2010). High diversification of export can be achieved through innovation and staying ahead of other countries. The theory also suggests that high export diversification is directly linked to increased economic growth.

\subsubsection{Endogenous growth theory}

The model suggests that the country's initial comparative advantage determines the products it can produce and hence its rate of human capital accumulation (Dornbusch, Fischer, and Startz, 2008). Moreover, the model appreciates the fact that the degree of goods diversification and increases in export diversification has a positive effect on the country's human capital accumulation (Mayer, 1996). In other words the more a country's basket of exports is diversified the higher the rate of human accumulation, leading to higher productivity and hence increased economic growth.

\subsection{Empirical literature}

Various studies have been conducted on the relationship between export diversification and economic growth. However, literature from South Africa is scarce, with only a few studies being conducted on the topic and related topics. Petersson (2005) employed linear regression method to investigate export diversification and intra-industry trade in South Africa. Results from the study suggested that reduced export concentration led to positive terms of trade and increases in economic growth. Matthee and Naude (2007) used Ordinary Least Squares (OLS) to examine the impact of export diversity on regional growth. The authors found out that diversifying into manufactured products was very beneficial to developing countries as it brought about a lot of spill-overs such as the introduction of new technology and knowledge.

Ar-Marhubi (2000) employed the OLS approach to empirically investigate the relationship between export diversification and growth. The findings of the study by Ar-Marhubi (2000) suggest that export diversification affects growth indirectly by stimulating the accumulation of capital especially in developing countries. In addition, Ar-Marhubi (2000) points out that it is detrimental to add distortions to the economy in the light of promoting export diversification, because distortions maybe against the comparative advantage of the economy.

Herzer and Nowak-Lehmann (2006) used annual time series data and employed Dynamic (OLS) to investigate the 
impact of export diversification and growth in Chile. Herzer and Nowak-Lehmann (2006 suggest that increased levels of horizontal export diversification into totally new products could generate positive externalities to the economy as a whole through dynamic learning activities and spill-overs. Similar conclusions were reached in the relationship between export diversification and economic growth by various authors such as Agosin (2007) and Ferreira (2009).

However, Nicet-Chenaf and Rougier (2008), points out that too much export diversification may be detrimental to the growth of the country. The author used GMM and focused on Tunisia, Egypt, Jordan, Morocco, Algeria and Israel. On the same note Aditya and Roy (2009) reached similar conclusions on the effect of export diversification on growth. The study used GMM also and took into consideration data from 68 countries.

\section{An Overview of Export Diversification in SA}

South Africa's export structure significantly changed from the early 1980s to the late 2000 s. The export basket changed with the mining sector being replaced by the manufacturing sector as the leading exporting sector in the country. The bulk of the mining products exported were gold which made more than $35 \%$ of the total merchandise exports. This led to South Africa's total exports to experience a trend of increasing export diversification between 1993 and 1999, into other sectors of the producing industries such as manufacturing exports.

Using the value of net exports from different sectors, South Africa's comparative advantage in exports continued to be strong in mining and metals products even in the 2000s. Other net exports from agriculture, beverages, tobacco, and refined products are small. On the same note, sectors such as automobiles, other machinery and equipment, food and leather products are exported in large amounts, but are offset by even larger imports in the same products. It is only in mining, specifically gold, platinum, iron ore, and coal, that South Africa has large net exports (Hausmann and Klinger, 2006). Table 1 serves to illustrate the South African export structure for 1985, 1990, 1995, 2000, 2005 and 2010.

Table 1: Export share of products in the South African export basket

\begin{tabular}{|l|c|c|c|c|c|c|}
\hline & $\mathbf{1 9 8 5}$ & $\mathbf{1 9 9 0}$ & $\mathbf{1 9 9 5}$ & $\mathbf{2 0 0 0}$ & $\mathbf{2 0 0 5}$ & $\mathbf{2 0 1 0}$ \\
\hline Agricultural products & 3620 & 4376 & 8658 & 22678 & 33374 & 57596 \\
\hline Fuels \& mining products & 6341 & 10136 & 17279 & 37894 & 97507 & 223415 \\
\hline Manufactures & 7345 & 21524 & 489534 & 97073 & 165871 & 240453 \\
\hline Iron and steel & 0 & 5610 & 10101 & 19128 & 37306 & 56637 \\
\hline Chemicals & 0 & 2075 & 7167 & 14252 & 25161 & 37175 \\
\hline Pharmaceuticals & 0 & 0 & 0 & 749 & 846 & 1230 \\
\hline Machinery\& transport Equip & 0 & 2515 & 8988 & 31694 & 60907 & 98491 \\
\hline Office \& telecom equip & 0 & 0 & 765 & 2837 & 3861 & 5404 \\
\hline Electronic data processing \& office equip & 0 & 0 & 319 & 978 & 995 & 1647 \\
\hline Telecommunications equip & 0 & 0 & 355 & 1685 & 2036 & 2387 \\
\hline circuits \& electric components & 0 & 0 & 91 & 173 & 827 & 1369 \\
\hline Automotive products & 0 & 644 & 2648 & 11845 & 27687 & 49073 \\
\hline Textiles & 240 & 432 & 863 & 1644 & 1985 & 1691 \\
\hline Clothing & 118 & 0 & 596 & 1512 & 1101 & 740 \\
\hline
\end{tabular}

Source: Own graph constructed from data available, WTO, 2012

From Table 1, South Africa's exports basket composition was mainly dominated by the mining sector prior to independence with the sector accounting for more than $15 \%$ of the country's total exports in 1985 (Faulkner \& Loewald, 2008).

Exports from these sectors accounted for $43 \%$ in 1985 and $60 \%$ in 1990 of the total export basket. It can be seen from Table 1, that the country expanded the number of products in the export basket from less than 7 in 1985 to more than 12 in 1995. In 1985 the primary products group accounted for more than $25 \%$ of the South African export basket, with manufacturing exports accounting for only $18 \%$ (Naude \& Rossouw, 2008).

The newly introduced exports have increased momentously since their introduction, from Table 1 it can be noted that the newly introduced products constituted $37 \%$ of total exports in 2005 from only $11.7 \%$ in 1995 . By 1995 manufactured goods contributed $49.44 \%$ higher than the mining sector which contributed $44.81 \%$ to South Africa's total exports. The mining sector's share declined from $54.79 \%$ in 1992 to $40.52 \%$ in 2010 . The manufacturing sector contributed $54.99 \%$ of exports in 2010 compared to $39.41 \%$ it contributed in 1992. In 1999, the manufacturing sector was 
the most significant contributor to the GDP of South Africa as it accounted for at least $20 \%$ of the value added in the country. From figure 2.1 it can be noted that the share of agricultural products in total exports slightly increased from $3.66 \%$ in 1992 to $4.18 \%$ in 2010 . The share of other trade declined during the period of 1992 to 2010 from $2.13 \%$ to $0.32 \%$ respectively (Petersson, 2005).

\section{Methodology}

\subsection{Model specification}

The study used South African annual data covering the period of 1980 to 2010. Most of the data was obtained from the South African Reserve Bank (SARB) online statistical query publications. Data on individual exports products breakdown was obtained from the World Trade Organisation website. In order to measure the impact of export diversification on economic growth in South Africa, this study modified the model used by Arip, Yee and Karim (2010), in the study entitled export diversification and economic growth in Malaysia. The authors used Gross domestic product (GDP) as the dependent variable with the degree of specialisation and diversification, employment and capital expenditure being explanatory variables. The model used in this study is as shown below.

$$
L G D P=\beta_{0}+\beta_{1} L N H I+\beta_{2} H U M+\beta_{3} L C A P+\beta_{4} L R E E R+\beta_{5} L O P E N+\varepsilon
$$

Where GDP is gross domestic product per capita, NHI is Normalised-Hirschmann Index, HUM is human capital formation, CAP is capital formation, REER is real effective exchange rate, OPEN is trade openness, L is logarithm and $\varepsilon$ is the error term, which represent the influence of omitted variables in the specification of the model.

\subsection{Data analysis}

\subsubsection{Testing for stationarity or unit roots}

Mahadeva and Robinson (2004) define stationary series as those with a constant mean, constant variance and constant auto-covariances for each given lag. Stationarity was tested for using the Augmented Dickey Fuller (ADF) and PhillipPerron (PP) tests. The results of the PP tests are shown in Table 2.

Table 2: Stationarity tests: Phillip-Perron tests

\begin{tabular}{|c|c|c|c|c|c|}
\hline \multirow{2}{*}{\multicolumn{2}{|c|}{ Variables }} & \multicolumn{2}{|c|}{ Phillip-Perron tests (Intercept) } & \multicolumn{2}{|c|}{ Phillip-Perron tests (Trend and Intercept) } \\
\hline & & Level & 1st difference & Level & $1^{\text {st }}$ difference \\
\hline \multirow{2}{*}{\multicolumn{2}{|c|}{$\begin{array}{l}\text { GDP } \\
\text { (P value) }\end{array}$}} & 1.4582 & $-4.6793^{*}$ & -0.9740 & $-4.8293^{*}$ \\
\hline & & 0.9988 & 0.0037 & 0.9329 & 0.0029 \\
\hline \multicolumn{2}{|l|}{$\begin{array}{l}\mathrm{NHI} \\
(\mathrm{P} \text { value })\end{array}$} & $\begin{array}{c}-2.4099 \\
0.1476\end{array}$ & $\begin{array}{c}-12.6962^{*} \\
0.0000\end{array}$ & $\begin{array}{c}-4.7917^{*} \\
0.0031\end{array}$ & $\begin{array}{c}-12.8179^{*} \\
0.0000\end{array}$ \\
\hline \multicolumn{2}{|l|}{$\begin{array}{l}\text { CAP } \\
\text { (P value) }\end{array}$} & $\begin{array}{l}0.3966 \\
0.9794\end{array}$ & $\begin{array}{c}-3.4009^{* *} \\
0.0307\end{array}$ & $\begin{array}{r}-1.2077 \\
0.8907\end{array}$ & $\begin{array}{c}-3.5659^{* \star *} \\
0.0474\end{array}$ \\
\hline \multicolumn{2}{|l|}{$\begin{array}{l}\text { HUM } \\
\text { (P value) }\end{array}$} & $\begin{array}{l}-0.3609 \\
0.9037\end{array}$ & $\begin{array}{c}-3.2298^{\star \star} \\
0.0283\end{array}$ & $\begin{array}{c}-1.4278 \\
0.8315 \\
\end{array}$ & $\begin{array}{c}-3.6120^{\star *} \\
0.0232\end{array}$ \\
\hline \multicolumn{2}{|l|}{$\begin{array}{l}\text { REER } \\
\text { (P value) }\end{array}$} & $\begin{array}{c}-2.1973 \\
0.2113\end{array}$ & $\begin{array}{c}-4.6814^{*} \\
0.0008\end{array}$ & $\begin{array}{c}-2.5484 \\
0.3045\end{array}$ & $\begin{array}{c}-4.6949^{*} \\
0.0049\end{array}$ \\
\hline \multicolumn{2}{|l|}{$\begin{array}{l}\text { OPEN } \\
\text { (P value) }\end{array}$} & $\begin{array}{l}-0.029 \\
0.9495\end{array}$ & $\begin{array}{l}-5.815^{\star} \\
0.0000\end{array}$ & $\begin{array}{c}-3.622^{\star *} \\
0.0453\end{array}$ & $\begin{array}{l}-5.680^{*} \\
0.0003\end{array}$ \\
\hline \multirow{3}{*}{ Critical values } & $1 \%$ & -3.6702 & -3.6793 & -4.2967 & -4.3098 \\
\hline & $5 \%$ & -2.9639 & -2.9677 & -3.5683 & -3.5742 \\
\hline & $10 \%$ & 2.6210 & -2.6229 & -3.2183 & -3.2217 \\
\hline
\end{tabular}

From table 2 it can be seen that all the variables are not stationary in levels. This is revealed in most $p$-values being greater than 0.05 , meaning that we failed to reject the null hypothesis of the existence of unit roots. After differencing, all the variables have $p$-values less than 0.05 , and hence are stationary. 


\subsection{Presentation and interpretation of results}

\subsubsection{Vector Error Correction Model (VECM)}

The VECM was be used to analyse the long run and short run effects of the variables on the dependent variable. The VECM is specified basing on the results of the cointegration tests and its results are shown in Table 3 . The interpretation of the results is explained in equation 1.2.

Table 3: Results of the long run cointegration equation

$\begin{array}{lccc}\text { Variable } & \text { Coefficient } & \text { Standard error } & \text { t-statistic } \\ \text { Constant } & -10.35165 & - & - \\ \text { GDP(-) } & 1.000000 & - & - \\ \text { NHI(-) } & 0.462022 & 0.11557 & 3.99790 \\ \text { REER(-) } & 0.543505 & 0.09686 & 5.61137 \\ \text { OPEN(-) } & 0.058409 & 0.22618 & 0.25825 \\ \text { HUM(-) } & -0.195425 & 0.08014 & -2.43849 \\ \text { CAP(-) } & -0.311734 & 0.08966 & -3.47681\end{array}$

The long run effect of export diversification and other factors that are affect export diversification and trade can be illustrated as in equation 1.2

GDP $=-10.352+0.462 \mathrm{NHI}-0.195$ HUM -0.311 CAP +0.544 REER +0.058 OPEN

From equation 1.2 it can be deduced that HUM and CAP have a negative long run relationship with GDP. The results suggest that a unit increases in HUM and CAP lead to a decline in GDP by approximately 0.195 and 0.311 respectively. The negative relationship between CAP and HUM is against the theoretical underpinnings which suggest that increases in both capital and human capital increases GDP. However, increases in HUM can start to affect GDP positively in the future when the educated and skilled labour force start to produce goods while reducing current GDP.

Both $\mathrm{NHI}$ and OPEN have positive relationships with GDP in the long run. The results in Table 3 suggest that a unit increase in $\mathrm{NHI}$ increases GDP by approximately $46.20 \%$. The positive relationship between NHI and GDP is in consistence with theoretical under suggestions which argue that increased export diversification also increases GDP. On the same note, a unit increase in OPEN also causes increases in GDP of about 0.058 . According to theory openness can either have a negative or a positive relationship with GDP depending on the whether the trade has got relatively more exports to imports or vice-versa. REER has a positive coefficient in equation 1.2, meaning that an increase in the real effective exchange rate (depreciation) causes an increase in GDP. According to the long run of this study, a unit percentage decrease in the value of the Rand causes approximately $58.41 \%$ increase in GDP. In general terms REER has a negative relationship with GDP, and the negative relationship between REER and GDP is in line with theoretical underpinnings since theory suggests that an increase in REER (depreciation) is associated with declining terms of trade consequently reducing balance of trade due to the fact that imports become dearer and exports prices decrease after the depreciation.

Table 4: Error correction results

$\begin{array}{lccc}\text { Variable } & \text { Coefficient } & \text { Standard error } & \text { t-statistic } \\ \text { GDP } & 0.084387 & 0.15637 & 0.53966 \\ \text { NHI } & -3.041284 & 0.77943 & -3.90192 \\ \text { REER } & -0.361619 & 0.47613 & -0.75950 \\ \text { OPEN } & 1.074700 & 0.25073 & 4.28622 \\ \text { HUM } & -0.258141 & 0.55550 & -0.46470 \\ \text { CAP } & 0.399790 & 0.32489 & 1.23053\end{array}$

The coefficient of GDP is approximately 0.084 implying that the speed of adjustment is around $8.4 \%$. In other words of the variation from the equilibrium for GDP, only $8.4 \%$ is corrected for annually. The correction happens during the time when the variable is moving towards equilibrium. This means that there is slow speed of adjustment of GDP which maybe reflect little pressure on the variable in restoring to the equilibrium in the long run due to any disturbance. The speed of adjustment is however not statistically significant with a t-value of around 0.5397. The slow speed of adjustment of GDP 
maybe interpreted as that there are other variables other than the ones specified in the model that affects GDP such as interest rates, monetary policy, fiscal policy and demographic factors.

\subsection{Diagnostic checks}

The fitness of the model was tested in three main ways. Firstly, serial correlation shall be tested using the langrage multiplier (LM) test, followed by the White test for heteroskedesticity and finally the Jarque-Bera for normality test. Diagnostic checks results are shown in table 5.

Table 5: Diagnostics checks results

\begin{tabular}{|l|l|c|c|}
\hline Test & Null hypothesis & t-statistic & Probability \\
\hline Langrage Multiplier (LM) & No serial correlation & 9.263 & 0.613 \\
\hline Jarque - Bera (JB) & There is a normal distribution & 0.525 & 0.769 \\
\hline White (CH-sq) & No conditional heteroskedasticity & 566.07 & 0.268 \\
\hline
\end{tabular}

From Table 5 it can be seen that the test for serial correlation has a statistic of 9.263 with a probability of 0.613 .The LM statistic of 9.263 imply that the null hypothesis of no serial correlation cannot be rejected. The results in Table 5 show a Jarque-Bera statistic of 0.525 with a probability of 0.769 . Since the probability is above 0.05 the null hypothesis of normal distribution is not rejected.

\section{Conclusions and Recommendations}

The data was analysed using the VECM methodology and was first tested for stationarity using ADF and PP tests. Stationarity tests revealed that all variables where stationary in their first difference. Cointergration and vector error correction modelling was also done. One lag was used in the cointegration analysis and both the trace and eigen-value cointegration test reflected that there was at least one cointegrating equation at $5 \%$ significance level. All the explanatory variables proved to be statistically significant in explaining GDP. The pair-wise correlation matrix was also used to determine the exact relationship between the four variables involved in this study.

Diagnostic tests, impulse response and variance decomposition analysis were also carried out and shown that the GDP model used in the study is quite suitable in capturing the influence of the explanatory variables in South Africa. The long run equation constructed from vector error correction modelling shows that GDP is positively related to export diversification, real effective exchange rate, and trade openness and negatively related to human capital and capital investment. Since most of the relationships estimated in the study are in consistency with theoretical underpinning and because the diagnostic checks and variance decomposition

Based on the results of this study the South African government can be advised to continue engaging implementing trade liberalisation policies. In other terms the South African government can embark on a policy in which it can subsidise small to medium scale firms that engage in the innovation and production of new products. The support to such firms will increase future possibilities of a diversified export basket for the country.

More so, the South African government should also take into consideration that trade openness is also a very important growth contributor. Hence, policy makers may be advised to also give positive attention to potential exporters and importers. In other terms, the government can engage in export subsidisation and the create policies such as reducing import tariffs and duties to create a more free trade environment. The country can also enhance trade openness by being involved in economic integration through joining of trade blocks. However, this must be done with caution due to the fact that increased trade openness and globalisation makes the economy to be more vulnerable to global shocks such as financial crisis and credit crunches occurring it the trade partners.

\section{Limitations of the Study}

The use of a simplified model is a major limitation faced in the study. Due to unavailability of data not all actual variables as suggested by theory could be included in the model. Furthermore, the study suffered from limited and inconsistency secondary data. Some data such as the data for exports goods classes was not readily available in the local currency (rands) and therefore had to be converted from US dollars making the data subject to mistakes and results inconsistence. However, the limitations did not lead to loss of statistical significance since the results are supported by both theoretical 
and empirical literature. Future studies may focus on the extent to which export diversification can continue to be a source of economic growth in South Africa

\section{References}

Aditya, A., \& Roy, S. S. (2009). Export diversification and economic growth. Evidence from cross country analysis. [Online] Available: http://www.isid.ac.in/ pu/conference/dec_10_conf/Papers/AnweshaAditya.pdf (February 22 2012)

Agosin, M, R. (2007). Export diversification and growth in emerging countries. [Online] Available: http://www.econ.uchile.cl/uploads/publicacion/7fec2632-b4c3-45a3-ab78-0970614f5bab.pdf (March 18 2012).

Agosin, M. R., Alvarez, R., \& Bravo-Ortega, C., (2009). Determinants of export diversification around the world: 1962-2000. [Online] Available: www.econ.uchile.cl/SDT (May 2 2011)

Appleyard, D. R., Field, A. J., \& Cobb, S. L. (2010). International Economics. (7th ed.). New York: McGraw-Hill Companies Inc.

Arip, M. A., Yee, L. S., \& Karim, B. A. (2010). Export diversification and economic growth in Malaysia. [Online] Available: http://mpra.ub.uni-muenchen (March 01 2012)

Ar-Marhubi, F., (2000). Export diversification and growth: an empirical investigation. Applied Economics Letters, 559, 2-5.

Brenton, P., Newfarmer, R., \& Walkenhorst, P. (2007). Export diversification: a policy portfolio approach. [Online] Available: http://www.growthcommission.org (February 25 2012).

Chandra, V., Boccardo, J., \& Osorio, I. (2007). Export diversification and Competitiveness in Developing Countries. [Online] Available: http://www.siteresources.worldbank.org (April 25 2011).

Dornbusch, R., Fischer, S., \& Startz, R. (2008). Macroeconomics. (10th ed.). New York: McGraw-Hill Companies Inc

Du Plessis, S. J. P., Smit, B. W., \& McCarthy, C. L. (2000). International economics (2nd ed.). South Africa: Heinemann publishers

Ederington, J., \& McCalman, P. (2009). International trade and industrial dynamics. International Economic Review, 961, 4-20

Faulkner, D., \& Loewald, C. (2008). Policy Change and Economic Growth: A Case Study of South Africa. [Online] Available: http://www.econrsa.org/papers/p_papers/pp14.pdf (April 25 2012].

Ferreira, G. F. (2009). The expansion and diversification of the export sector and economic growth: The Costa Rican experience. [Online] Available: http://etd.Isu.edu/docs/available/etd-08122009-154515/unrestricted/Ferreiradiss.pdf (February 26 2012)

Hausmann, R., \& Klinger, B. (2006). South Africa's export predicament. Economics of Transition. 609, [Online] Available: http://onlinelibrary.wiley.com/doi/10.1111/j.1468-0351.2008.00337.x/pdf (April 25 2012).

Herzer, D., \& Nowak-Lehnmann, D. F., (2006). What does export diversification do for growth? An econometric analysis. [Online] Available: http://peer.ccsd.cnrs.fr/docs/00/58/18/78/PDF/PEER_stage2_10.1080\%252F00036840500426983.pdf (April 25 2012).

Mahadeva, L., \& Robinson, P. (2004). Unit Root Testing to help Model Building. Handbooks in Central Banking No. 22. UK: Bank of England

Matthee, M., \& Naude, W. (2007) Export diversity and regional growth empirical evidence from South Africa. [Online] Available: http://www.unitn.it/files/download/19156/wp162008mattheeandnaude.pdf (May 21 2011)

Mayer, J. (1996). Implications of new trade and endogenous growth theories for diversification policies of commodity-dependent countries. [Online] Available: http://www.unctad.org (May 22 2011)

Naude, W., \& Rossouw, R. (2008). Export diversification and specialization in South Africa: Extent and impact. [Online] Available: http://www.csae.ox.ac.uk (February 22 2012)

Nicet-Chenaf, D., \& Rougier, E. (2008). FDI, Diversification and Growth. An Empirical assessment for MENA countries. [Online] Available: https://www.gate.cnrs.fr/unecaomc08/Communications\%20PDF/Texte\%20Nicet\%20Chenaf_Rougier.pdf (May 26 2011)

Nouira, R., Plane, P., \& Sekkat, P. (2009). Exchange rate undervaluation and export diversification: a deliberate strategy. Economic Research forum. [Online] Available: http://cerdi.org/uploads/ed/2011/2011.25.pdf (May 20 2011)

Petersson, L. (2005). Export diversification and intra-industry trade in South Africa. South African journal of economics, 73, 785-802

Salvatore, D. (2007). International Economics. (9th ed.). USA: John Wiley \& Sons Inc

Samen, S. (2010). Export development, diversification, and competitiveness: How some developing countries got it right? Available: http://www. blogs.worldbank.org (May 22 2011)

WTO. (2012). Merchandise trade by commodity in US dollar at current prices (Millions). [Online] Available: http://stat.wto.org/StatisticalProgram/WSDBViewData.aspx?Language=E (20 April 2012). 